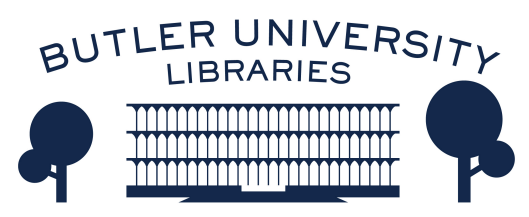

Journal of Hindu-Christian Studies

Volume 23

Article 9

January 2010

\title{
Vidyaranya Swami's "pañca viveka" and Thomas Aquinas' "quinque viae" in the Light of Today's Science
}

Klaus K. Klostermaier

Follow this and additional works at: https://digitalcommons.butler.edu/jhcs

Part of the Religion Commons

\section{Recommended Citation}

Klostermaier, Klaus K. (2010) "Vidyaranya Swami's "pañca viveka" and Thomas Aquinas' "quinque viae" in the Light of Today's Science," Journal of Hindu-Christian Studies: Vol. 23, Article 9.

Available at: https://doi.org/10.7825/2164-6279.1461

The Journal of Hindu-Christian Studies is a publication of the Society for Hindu-Christian Studies. The digital version is made available by Digital Commons @ Butler University. For questions about the Journal or the Society, please contact cbauman@butler.edu. For more information about Digital Commons @ Butler University, please contact digitalscholarship@butler.edu. 


\title{
Vidyāraṇya Swāmī's pañca viveka and Thomas Aquinas' quinque viae in the Light of Today's Science
}

\author{
Klaus K. Klostermaier \\ Professor Emeritus, University of Manitoba
}

\author{
"Brahman cannot be seen, but through \\ reasoning ${ }^{1}$ and revelation ${ }^{2}$ its \\ existence can be ascertained." \\ Vidyāranya (1268- 1350), Pañcadaśî VI, \\ $167^{3}$
}

"From the effects of God it can be demonstrated that God is."

Thomas Aquinas (1225-1274), Summa theologica I, 2, 2 ad $3^{4}$

"Man knows at last that he is alone in the universe's unfeeling immensity, out of which he emerged only by chance."

Jacques Monod (1910-1976), Chance and Necessity ${ }^{5}$

IN the context of recent attempts to shore up atheism with philosophical and scientific arguments $^{6}$ the construction of rational proofs for the existence of God is receiving renewed attention. Over against the assertion of some scientists that religious belief is both unscientific and irrational, philosophers and theologians argue that the study of nature itself offers a great deal of evidence for the existence of a Creator. They are supported by numerous reputable scientists, the authors of book titles like The Language of $\mathrm{God}^{7}$ or The Mind of $\mathrm{God}^{8}$ and many others. It is noteworthy that Google has over two million entries under the term 'proofs of god.' Its extremely long Wikipedia article ranges widely and includes Christian and Hindu proofs of the existence of God as well as traditional and contemporary arguments against it.

It is not my intention in this paper to roll out the entire problematic connected with the issue of 'proofs of god' or to deal with the historical contexts to the Pancadaś $\bar{I}^{-}$and the Summa theologica. To do so would require a book-length essay. Nor do I wish to cover the entire spectrum of Christian and Hindu contributions to this problematic. ${ }^{10}$ I simply found it intriguing to juxtapose the quintet of Vidyāranya's pañca vivekas and of Aquinas' quinque viae and to attempt figure out how they would hold up to present-day scientific arguments.

"Natural Theology" flourished in the $18^{\text {th }}$ century, when the foundations to many of the modern sciences were laid. It was popular in English universities at a time when most of the science teachers were also members of the clergy. William Paley's (1743-1805) Natural Theology or Evidence of the Existence and Attributes of the Deity, Collected from the Appearances of Nature (1802) was used as a standard text at Cambridge University for half a century. Charles Darwin also read it and Richard Dawkins, perhaps the bestknown contemporary 'scientific atheist,' alluded to one of its more famous passages in the title of his

Klaus K. Klostermaier, Fellow of the Royal Society of Canada, Distinguished Professor Emeritus, University of Manitoba, is the author of numerous books and articles on Hinduism, e.g. A Survey of Hinduism, SUNY, $3^{\text {rd }}$ edition 2007 and Hinduism: A Short Introduction, Oneworld: Oxford, $4^{\text {th }}$ printing 2008. He has been engaged in Hindu-Christian dialogue since the 1960s (cf. Christian and Hindu in Vrindaban, SCM London 1971). One of his major interests has been the Science-Religion dialogue. He team-taught graduate courses in this area with science-faculty and was the recipient of a Templeton Foundation Course Award (1995). Among his publications in this area is The Nature of Nature: Explorations in Science, Philosophy and Religion, Theosophical Publishing House: Adyar, 2004. 
The Blind Watchmaker. Some later Protestant theologians rejected Natural Theology as unbiblical $^{11}$, but today it is experiencing significant revival and revitalization. ${ }^{12}$ Wolfhart Pannenberg, a Lutheran theologian, published in 1993 a collection of essays under the title Towards a Theology of Nature: Essays on Science and Faith. ${ }^{13}$ Alister E. McGrath, an Anglican theologian with a solid background in science, recently published a series of lectures under the title The Open Secret: A New Vision for Natural Theology. ${ }^{14}$ In his textbook Science and Religion he devoted an entire chapter to "Proofs for God's Existence." 15

In Catholic circles Thomas Aquinas' "Five Proofs for the Existence of God" $^{16}$ have remained popular throughout the ages. They were a staple in texts on Theologia Naturalis, a branch of the philosophical propaedeutics to theology proper. The recently published Catechism of the Catholic Church $^{17}$ states unequivocally that: "The existence of God the Creator can be known with certainty through his works." ${ }^{18}$ Christian apologists, who used philosophical and scientific arguments to prove the existence of God, thereby attempted to show that their faith had a reasonable foundation.

In India, Hindus were engaged for many centuries in polemics with the Buddhists who denied a Creator and an all-embracing divine providence on the basis of empirical knowledge and logical arguments. Buddhist and Hindu scholars passionately debated this issue, which dominated Indian philosophy for over a thousand years. Sāntarakșita's Tattvasamgraha ( $8^{\text {th }}$ century) - summarizing centuries of Hindu-Buddhist controversies on a great many critical issues contains many chapters that refute Hindu notions of creator and creation. ${ }^{19}$ Śankara ( $8^{\text {th }}$ century?) in his Brahmasütrabhāṣya devotes considerable space to a refutation of several Buddhist positions. ${ }^{20}$ The Buddhist teaching of sūnyatä as ultimate ground of all phenomena appeared to be in direct conflict with the Vedāntic affirmation of brabman as saccidānanda. If Buddhists considered universal 'emptiness' as the last truth about the world, the Vedāntins emphasized brahman as the real ground of everything. In that tradition Vidyāranya offers his proofs for the existence of brahman - ultimate reality.
At the time of Thomas Aquinas there was no organized or institutionalized atheism in the West. Aquinas' arguments to prove the existence of God look more like an exercise in philosophy than as part of an existential debate. His (largely imaginary) opponents used some of the same arguments that modern atheists are proffering: if an infinitely good and all-powerful God existed, there should not be so much evil in the world. ${ }^{21}$ Since all things in this world can be explained naturally without recourse to the notion of God, there is no need to postulate a Creator. Aquinas attempted to prove the existence of a Creator-God with the help of the then commonly accepted Aristotelian four causes: efficient, material, formal and final. The atheists of his time - the addressees of the proofs - seem to have been few and fairly unsophisticated. They certainly were not organized and had no institutional basis. The position of the Church was too strong to allow effective contradiction.

The task that confronted Vidyāranya, the $14^{\text {th }}$ century Hindu ācārya, appears to have been more difficult: There was no central Hindu authority that prescribed a dogma-based faith and there were a great many different Hindu cosmogonies and theologies. Vidyāraṇya had to face a mature Buddhist scholastic tradition that had worked out its positions with considerable philosophical acumen. Apart from certain conventions, there was no commonly accepted philosophical canon and no agreement on epistemology. ${ }^{22}$ The Buddhists operated largely with arguments based on commonsense logic, quite persuasive even for ordinary people. ${ }^{23}$ Vidyaranya, convinced that tarka (formal logic) was not sufficient to settle the matter ${ }^{24}$, resorted to viveka (differentiation) to make his case. ${ }^{25}$ It was out of the question to construct a proof for the existence of transcendent brahman based on the perception of sense-objects: the ontological uniqueness (a-dvaita) of brahman would forbid such a procedure. In his Pañcadasí Vidyāranya differentiates the immaterial from the material, the eternally existent from the transient and thus reveals both its reality and its difference from the things of sense-experience, the basis of the Buddhist atheistic argument. He explains that the purpose of his exercise was to offer easy access to Brahman-knowledge for those "whose hearts have been purified by service at the feet of 
the guru." ${ }^{26}$ This "moral qualification" is usually left out in the contemporary debate!

\section{Vidyāraṇya's and Aquinas' Proofs}

Vidyaranya's opus magnum, the Pañcadasi $I^{27}$, is divided into three parts containing five chapters each: Chapters I - V are dealing with five kinds of viveka, Chapters $\mathrm{VI}-\mathrm{X}$ with five varieties of dipa, Chapters XI - XV with five levels of ānanda.

It is the first section that this essay is focusing upon. Viveka differs from the customary logical proof insofar as it does not draw a conclusion from a major and minor with the help of the axioms of formal logic, but it aims at differentiating something particular out from a given complex. The standard lexicon translation of viveka is "discrimination." By using the term "proof" I am intending to suggest a verbal parallel to Aquinas' "proofs." It is not suggested that the Vedāntic viveka and the Aristotelian syllogism are formally the same.

Aquinas' opus magnum, the Summa theologica, relying on Biblical revelation and the teachings of the Church as its main source, devotes only a comparatively small fraction of its content (Articulus 3 of Quaestio 2 of Pars Prima of the Summa theologiae, which comprises several thousand such Articuli) to the philosophical proofs for the existence of God.

Since the renewed interest in arguments for the existence of God has been kindled by the contemporary encounter between religion and science, it stands to reason to examine the traditional arguments from the viewpoint of today's sciences. While religions do not and should not base their own truths on the sciences of the day, there are areas in the domains of the sciences that religions must respect. Whereas for Jews and Christians (and Muslims) belief in a Creator God, as the Bible proclaims it, will not be shaken by any scientific argument, the belief that the world was created only six-thousand years ago, and that everything on earth came into existence within a period of six days - as the Genesis narrative has it - has become clearly untenable in the light of the generally accepted findings of Paleontology and Paleobiology, and it does not help the cause of religion to cling to it. Similarly, philosophical presuppositions, once accepted as authoritative, must be corrected by factual evidence, when available. Aristotle certainly still deserves respect for his manifold contributions to the world of philosophy, but some of his presuppositions are no longer acceptable in the light of the findings of contemporary Physics and Astrophysics.

\section{Vidyāranya's Tattva-viveka: the "ontological proof."}

After identifying the ontological status of avidyā as rooted in the kāraṇa-śāriram (I, 17), the lowest of the layers of bodily existence ${ }^{28}$, Vidyaranya explains the arising of the five subtle elements "at the command of iśvara for the experience of the jīva." (18) He uses viveka as the means "for extracting the Self." Referring to the commonly accepted pañca-kośa notion, he states: "By differentiating the Self from the five sheaths through the method of distinguishing between the variable and the invariable, one can draw out one's own Self from the five sheaths and attain the supreme Brahman." (37) There is logical proof (yukti) for the identity of brahman and attman as well as scriptural proof (śruti) in the Upanișadic formula tat-tvam-asi. The steps that lead to the realization of brahman as different from the world of objects are the well known smarana, manana, nidhidhyāsana, and samādhì.

Aquinas' First Proof is based on the notion of causality involved in the physical movement of solid bodies: a certainty, as he says, and founded on sense perception (certum est et sensu constat aliqua moveri in hoc mundo). He assumes, as an equally certain and common conclusion, that all that is moved is being moved by something or somebody (Omne autem quod movetur, ab aliquo movetur). It is similarly logical to trace all movements eventually to a source that is moving others, but that is not moved by something or somebody else (necesse est devenire ad aliquod primum movens, quod a nullo movetur). And this, he concludes, all understand to be God (et hoc omnes intelligunt Deum).

Contemporary scientists would not consider the five kośas that Vidyāranya refers to as valid objects for scientific investigation, but the process of differentiation of subjective consciousness from objective sense experience would still work today. 
Nobel prize winning physicist Erwin Schrödinger deplored the fixation of Western science on objectivity and saw in it the source for its inability to deal with the whole of experienced reality, excluding from its scope 'all that is near and dear to us.' He identified this objectivity-fixation as the reason for the (necessary) absence of the notion of a personal deity in the scientific world picture: the modern scientific worldview was established by eliminating everything subjective - including God. ${ }^{29}$ According to Schrödinger, the insight of Advaita has not been invalidated by modern science - quite the opposite: he was prepared to offer empirical proof for it! $!^{30}$

Aquinas' proof, relying on Aristotelian physics and metaphysics, does not stand a chance with today's scientists: what he considered solid bodies have been dissolved by modern physics into assemblies of atoms consisting of energy quanta. The interdependence of everything in space and time as expressed in Einstein's Theory of Relativity would make it difficult to maintain the existence of a First Unmoved Mover, separate from the moving bodies, or to argue for the logical necessity of the existence of God on the basis of the movement of the planets. In an uncaused universe local causality does not carry very far.

It also poses an additional philosophical problem: how can an incorporeal entity directly impinge on the movement of material bodies?

2. Vidyāranya's Mahābhūta-viveka: the "cosmological proof."

Vidyāranya introduces the second viveka with the observation: "Brahman, who is according to sruti the non-dual reality, can be known by the process of differentiation from the five elements." (II, 1) Traditional Hindu physics, was built on the pañca-mahā-bhūta theory, the assumption that all material entities are a combination of the five original (eternal) elements: "The properties of the five elements are sound, touch, color, taste and smell. In ether, air, fire, water and earth the number of properties successively are one, two, three, four and five." (2) Without recourse to these elements "brahman can be experienced as pure existence in the cessation of all activities and this is not an experience of śunya, because we are not conscious of the perception of nothing" (44). An in-depth understanding of the nature of the elements and the world as being of māya-nature confirms the non-dual nature of Being. (98) Vidyāranya asserts that advaita-knowledge is permanent: no falsification can take place. (108) This particular viveka presupposes the assumption of brahman as the reality-ground of the world.

Aquinas' Second Proof is based on the first of Aristotle's four causes, the efficient, the only kind of causality that modern science recognizes. More precisely, he refers to a nesting of such causes in the objects of sense perception (invenimus in istis sensibilibus esse ordinem causarum efficientium). No thing can be its own efficient cause, because that would mean that it would exist before itself, which is patently impossible. (quia sic esset prius ipsius, quod est impossibile). Parallel to the first proof he concludes that it is necessary to assume a first efficient cause "which we all call God" (necesse est ponere aliquam causam efficientem primam: quam omnes Deum nominant).

As far as modern science is concerned, Vidyāranya's second viveka would find much the same response as the first. The categorical difference between sense-based objectivity and subjective consciousness has not been obliterated by modern science - even if some misplaced attempts have been made to objectify consciousness $^{31}$ and expressions like "artificial intelligence" wrongly suggest the identity of the human mind and man-made machines. ${ }^{32}$

It is different with Aquinas' second proof. Although modern science recognizes (efficient) causality in the realm that is subject to the known laws of nature, the beginning of the universe, generated by the "Big Bang," is termed a "singularity" i.e. an entity to which the known laws of physics do not apply and which is outside the cause-effect sequence. The assumption of an 'a-causal' beginning makes it impossible to argue from 'a first efficient cause' for the necessity of a Creator. By and large the same philosophical problem as in the case before arises, viz. the physical action of a non-physical entity.

3. Vidyāranya's Pañcakośa- viveka: the "biological proof." 
In the third chapter Vidyāranya offers a demonstration of brahman ("hidden in the cave") by differentiating 'being' out of the pañca kośas, the five "envelopes" that together form the living body. Listing the names, the composition and the properties of the five "sheaths" Vidyāranya progressively eliminates all attempts to identify any of them with atman. The "physical sheath" (anna-maya kośa) did not exist before birth and will not exist after death. (III, 3) The "vital-airs sheath" (präna-maya kośa) is devoid of consciousness. (5) The "mind sheath" (manamaya kośa) is subject to delusions. (6) The "intellect sheath". (vijāāna-maya kośa) is changeable. (7) And the "bliss-sheath" (annandamaya kośa) is impermanent. (10) The attman, however, is both real and permanent. The experience of the atman is not identical with the Buddhist śunya because nobody thinks: "I do not exist." (23 f) The attman is not 'this' or 'that, 'i.e. it is not an object: "Though it cannot be made an object of knowledge, the Self is experienced directly: it is self-revealing." (26-28) It shares with brahman the attributes of satyam, jñānam, anantam. The Self, as witness of the transient world, cannot be transient himself. The Upanișadic neti, neti is a negation of all objects that have name-and-form, but it asserts the existence of the atman. "The entire world that can be referred to as 'this' can be negated, but that which is not 'this' can never be negated: this indestructible witness is the attman." (33) In conclusion he can say: "Thus has been established the eternal existence of the Self which is Brahman, which is all-pervasive, not limited by space; eternal, not limited by time; of the nature of everything it is not limited by any object." (34-35)

Aquinas' Third Proof is more sophisticated than the previous ones: it operates with the notions of "possibility" and "necessity" (ex possibili et necessario). As the processes of generation and corruption show, the existence of some things is possible, but there is no ontological necessity for them to exist. In the face of this contingency it is necessary to assume something that is by and initself necessarily 'existing (necesse est ponere aliquid quod sit per se necessarium). This being must not be conditioned by something else (non habens causam necessitatis aliunde), but must itself be the cause for the necessity of others (quod est causa necessitatis aliis): and that, he says, "All call God."

Vidyāranya's third viveka presupposes the acknowledgement of the existence of a nonphysical reality: a 'soul.' Some scientists, such as Jacques Monod or Richard Dawkins, simply refuse to recognize anything as real that is not material. With them Vidyāranya's approach would not work. However, there are others, equally well or even better qualified scientists, for whom $\mathrm{mind} / \mathrm{spirit} / \mathrm{soul}$ is a reality and who recognize the limits of science 'with regard to statements concerning reality as such. Their number is large and it is an illustrious gallery: Max Planck, Arthur Eddington, James Jeans, Werner Heisenberg, Erwin Schrödinger, Wolfgang Pauli, Carl Friedrich von Weizsäcker, Erwin Chargaff, T. G. Dobzhansky, and many others. Hans-Peter Duerr, a prominent German physicists assumes that the universe itself possesses consciousness ${ }^{33}$ and categorically states: "What matter is made from certainly is not matter." ${ }^{34}$ The energy quanta that according to today's physics form the subatomic world have nothing in common with the crude "matter" equated with reality by $19^{\text {th }}$ century physics. Ervin Laszlo has revived the ancient Indian notion of akāśa to accommodate the most recent discoveries about non-locality and instant universe-wide communication. ${ }^{35}$

Of all of Aquinas' proofs this one seems to be the least time-bound, and scientists with some traditional philosophical background might agree with it. It does not depend on specific ephemeral scientific theories but uses time-less concepts that have not lost their validity. Unfortunately, $20^{\text {th }}$ $121^{\text {st }}$ century philosophy in its avatārs of Logical Positivism, Linguistic Analysis and PostModernism has traded in its metaphysical heritage for a pseudo-scientific vocabulary that leaves an empty space where notions like soul, spirit or God used to be placed. As Louise Young - herself a reputable scientist - has remarked: "Ideas lifted from science (and attributed a greater degree of certainty than they possess) have been transplanted into the sensitive area of the humanities. Here they have caused confusion, frustration and cynicism. It is considered sophisticated to accept gracefully 'the scientific fact' that the universe has no purpose and our lives are without meaning. ${ }^{136}$ 
Vidyāraṇya Swāmī's pañca viveka and Thomas Aquinas' quinque viae 33

4. Vidyāranya's Dvaita-viveka: the "metaphysical proof."

The fourth chapter of the Pañcadsii attempts to show that by exploring the limits of the world of duality one can arrive at the cognition of the non-dual reality of atman/brahman. It leads the student through the various levels of duality characterizing this world, in the process repeating the traditional Hindu cosmogony according to the Upanișads that brahman created the world and everything in it. (IV, $2 \mathrm{ff}$ ) The $j \bar{i} v a$, the individual person, is responsible for the creation of the feelings of happiness, disappointment and indifference in connection with the experience of objects. (22) Object-knowledge is twofold: material (mrn-maya) and mental (dhi-maya). The first category is cognized by the rational thinking mind (manas), the second by the witnessconsciousness (sāksin). "By the application of the double method of agreement and difference we come to the conclusion that it is the mental creation which causes bondage to the $j \bar{i} v a$ : for when mental objects are there, pleasure and pain are there too; when they are not, there is neither pleasure nor pain." (32)

Vidyaranya rejects the suggestion that he is advocating Buddhist Vijñānavāda. (36) Nor does he agree with the followers of Patañjala Yoga (38ff). His final conclusion is: "One, whose mind does no longer dwell on whether he knows brahman or not, but who remains identified with pure consciousness or knowledge is not merely a knower of brahman, but is brahman itself." (68)

Aquinas' Fourth Proof comes closer than the others to the way Vidyāranya argues. Reflecting more a Platonic than an Aristotelian reasoning it operates with the ontological transcendentals. There is a more or less of goodness, truth and nobility in all things (invenitur in rebus aliquid magis et minus bonum, et verum, et nobile). The maximum of these must be the cause of the individual instants of each (quod dicitur maxime tale in aliquo genere est causa omnium quae sunt illius generis). There must then be something that - for all entities - is the cause of their being, their goodness and whatever perfection it has (ergo est aliquid quod omnibus entibus est causa esse, et bonitatis, et cuiuslibet perfectionis): "And that we call God."

Modern psychology would agree with much of what Vidyāranya says about the imagined subjective nature of our world-picture. It would stop short of accepting his main point: viz. that the source of that imagination is not imagined but real and that by necessity its reality is categorically different from the world that it imagines.

Aquinas' fourth proof would still appeal to philosophically sensitive persons. Its Platonic coloring of language would make his conclusion acceptable also to those who do not subscribe to a Biblical notion of God but prefer a more neutral "Supreme Source," such as Ervin Laszlo's Plenum. ${ }^{37}$

\section{Vidyāraṇya's Mahãvākya-viveka: "scriptural proof."}

The fifth chapter is the shortest one of the first part of the Pañcadaśĭ, comprising a mere eight verses. It is, for an Advaitin, the most convincing proof. If the earlier four chapters used yukti to show the reality of brahman, this one has recourse to sruti. Its applicability to the present debate may lay in its focus on consciousness as ultimate reality and as source of everything. While clearly treating śruti as supra rational, Vedāntists always insisted that its revelations could be understood by a mind that has been purified from desire and greed.

Instead of selectively commenting on individual verses $I$ am reproducing the full text, which, I believe, is self-explanatory. It is a series of brief comments on four famous mahāvākyas, one from each of the four Vedas, summing up according to the Advaitins the teaching of the Upanișads.

"That by which one sees, hears, smells, speaks and distinguishes sweet and bitter etc. is called consciousness (prajūānam)." 38

"The one consciousness, which is in Brahmā, Indra and other devas as well as in human beings, horses, cows etc, is Brahman. So the consciousness in me is also Brabman."

"The infinite, supreme Self remains manifested in this world as the witness of the functions of the intellect in the body, fit for Selfknowledge and it is designated as I."39 
"By nature full, the supreme Self is described by the word Brahman. The word asmi [I am] denotes the identity of aham [I] and Brahman. Therefore 'I am Brahman."' (V, 4)

"Before creation there existed the Real, one only, without a second, and without name and form. That it exists even now in a similar condition is indicated by the word tat [that]. ${ }^{40}$

"The principle of consciousness which transcends the body, senses and mind of the enquirer is denoted by the word tvam [you]. The word asi [you are] shows their identity. That identity has to be experienced."

"By tat [that] is meant that the attman [self] is self-luminous and directly experienced. That is known as Pratyagātman [inner self] which is the indwelling principle covering everything between the ego-principle and the body."

Aquinas' Fifth Proof, like all others, proceeds on the basis of what he assumed to be undisputed facts and commonly accepted philosophical principles. Although the statement, which he wants to prove true, is a Scripture quote (Exodus 3,14: in the Vulgate translation Ego sum qui sum) he avoids using scriptural authority and endeavors to make his case on the basis of common reason. This particular proof is based on the Aristotelian notion of "final cause." Thomas does not doubt that certain things that do not possess cognition operate because of some end (aliqua quae cognitione carent, scilicet corpora naturalia, operantur propter finem). They reach that end not accidentally but by purpose (non a casu, sed ex intentione perveniunt ad finem). They could not pursue a purpose unless they were guided by someone with cognition and intelligence (non tendunt in finem nisi directa $a b$ aliquo cognoscente et intelligente) - like an arrow shot by an archer. For Thomas the only possible logical conclusion is that "there is something intelligent by whom all natural things are directed towards an end (Ergo est aliquid intelligens, a quo omnes res naturales ordinantur ad finem): "And that we call God."

As far as Vidyāranya's fifth viveka is concerned, for those of our contemporaries who equate truth with what has been scientifically established, a reference to scripture and revelation would be taboo. However, there are many scientists who - aware of the limitations of the scientific method - would listen to words of wisdom gained by insight. ${ }^{42}$-The aforementioned Erwin Schrödinger, for one, interiorized the mahāvākyas and recognized their truth at a level that is outside the realm of physics: we do have sources of knowledge that are not dependent on our senses. Others, like Francis Collins, would appropriately re-interpret Biblical passages, to separate timeless insights from timebound articulations.

Aquinas' quinta via is at the core of probably the fiercest contemporary intellectual battle: purpose or mere chance, meaning or meaninglessness, intelligent design or mere accident. There are legions of defenders and opponents to all these positions, and the evidence does not allow a final judgment. It is a question of presuppositions and of viewpoints. Hundreds of books have been written and dozens of conferences have been held on these questions, and there is no final conclusion in sight. Those who assume a Creator have powerful arguments in favor of purposefulness and meaningfulness of creation. Those who reject an ultimate intelligence muist also reject design, purpose and meaning. As long as both competitors remain honest and within the range of accepted procedures the debate can produce enlightening insights for all concerned.

\section{The Presence of Transcendence}

After settling the question of God's existence, Aquinas asks whether God is in all things ${ }^{43}$ and offers proofs for the ubiquity of God. "God is in all things, not as part of their essence, or like some accident, but in the way in which an agent is present to that which he does." (Deus est in omnibus rebus, non quidem sicut pars essentiae, vel sicut accidens, sed sicut agens adest ei in quod aget) $\mathrm{He}$ refers to Aristotle Physics VII, who said that "mover and moved must co-exist simultaneously." He concludes that "as long as a thing has being, it is necessary that God be present to it, according to the mode of its being" (quamdiu res habet esse, tamdiu oportet quod Deus adsit ei, secundum modum quo esse habet). Since being is the most intimate in everything God must be in all things intimately" (Esse autem est quod est magis intimum cuilibet... oportet quod Deus sit in omnibus rebus, et intime). 
Vidyāranya, who differentiates between the invisible brahman and the embodied is vara, locates issvara in the inmost recesses of the human being as the consciousness of the ananda-maya kośa. "Since iśvara abides in and activates and controls all the functions of the other kośas and all creation he is called the antaryamin (inner controller). ${ }^{44}$ The way this Inner Controller works has to be found out through śruti, it cannot be found out otherwise: "Sruti says that the Lord abides in the intellect and has the intellect as his body; but the intellect does not know Him; it is itself controlled by Him. ${ }^{45}$ The same source also tells us that: "as threads pervade a piece of cloth and constitute the material cause, so the Inner Ruler, pervading the whole universe, is the material cause of the universe. Just as the threads are subtler than the cloth and the fibers of the threads are subtler than the threads themselves, even so, where this progress from the subtle to the subtler stops, there do we confront the Inner Ruler." $^{46}$

Vidyāranya concludes his exposition with the lapidary sentence: "The essence (tattvam) of the entire visible universe is denoted by the word Brahman. That Brahman is of the nature of the self-luminous ātman." ${ }^{47}$

The physicist James Jeans (1877-1946) ended his reflections on the nature of physical reality with the observation: "It does not matter whether objects 'exist in my mind or that of any other created spirit' or not; their objectivity arises from their subsisting in the mind of some eternal Spirit."'48

\section{Alone in a purposeless universe?}

Having given Vidyāraṇya Swami and Thomas Aquinas their due, fairness requires to also address the third motto that prefaced this essay. Jacques Monod may have had his own personal reasons for his metaphysical despair: tragic events in his family as well as his close friendship with Jacques Camus, one of the great existentialists. However, as a general theory supposedly based on science, it is deeply flawed. It is an expression of the reductionism that was considered to be the scientific method: it began with Galileo, was perfected by Newton and had been followed by virtually all branches of modern sciences. It assumed that all phenomena could be explained as composites of particles in movement and could be described in equations that express the laws of nature. According to Steven Weinberg "All explanations point downwards." He also thinks that we exist in an "overwhelmingly hostile universe" and concludes that "the more the universe seems comprehensible, the more it also seems pointless. ${ }^{49}$

There is no intrinsic meaning in atoms and their movements. However, the universe does not only consist of atoms, and there is much in it that cannot be explained through the movement of atoms alone. Meaning is an "emergent" feature, as are life and mind. ${ }^{50}$ Nobody can deny the existence of life in the universe and nobody could have predicted the emergence of life by a study of the properties and behavior of atoms that constitute organisms. Nobody could have predicted the evolution of particular species either - we can only trace their emergence backwards. Nor do we know what kinds of things will emerge in times to come. The complexity of organic life makes it possible to have an endlessly unpredictable variety of organisms - no two bacteria are identical, not to mention human beings. Reality does not only reside in the most elementary building stones - the atoms - but also in the phenomena that emerged in the course of time: living organisms, humans, cultures.

Biologists - at least since Darwin's The Origin of Species - have been divided between those that saw the hand of God in the creation of organic life $\mathrm{s}^{51}$ and those that attributed all evolution to blind chance and natural selection. As Rupert Sheldrake has noted, the terms chance and natural selection are loaded with anthropomorphic baggage and are given attributes that were formerly associated with a Creator. In a section entitled "The Hidden Goddesses of Darwinism" Sheldrake points out that "instead of the heavenly father, Darwin saw in Mother nature the source of all forms of life." ${ }^{52}$ And Richard Dawkins, of The Selfish Gene fame, "takes anthropomorphism to an extreme unprecedented in science." ${ }^{53}$

The main contemporary (religious) opposition to biological materialism is predicated on "intelligent design" : - a rather vague notion suggesting some non-material element in the 
evolution of organisms. The major problem of those who advocate "intelligent design [ID]" is to locate it somewhere in the process of evolution. Suggestions like Michael Behe's - the most prominent representative of $\mathrm{D}$ - that it shows in the "irreducible complexity" of the structure of the cell or in the inexplicable construct of the bacterial flagellum, suffer under the suspicion of introducing a 'God-of-the-gaps': a gap that might be filled by later scientific discoveries. If anything, we have to see the 'designer' at work in the information that is an immaterial intrinsic part of all organisms, if we do not have the courage to see the Creator embodied in all creation, as the Hindu traditions do. The word 'design' suggests sketches and blueprints that are external to the objects made after them. In nature, there is no 'design' for an organism that could be separated from the living object itself. As David Suzuki remarked in The Sacred Balance, when discussing microbiology: "We expected a blueprint and found a living library."

The theory of evolution - in its NeoDarwinian rather than in its original Darwinian version - is being used by many scientists as proof against the existence of God: natural selection and chance have replaced divine creation and providence. ${ }^{54}$ Monod and Dawkins argue against the idea of a personal Creator God by pointing out what they perceive to be the insensitivity of nature towards suffering, the apparently needless cruelty that lets one species feed on another, and the seemingly pointless natural catastrophes that take the lives of untold numbers of living beings.

Some $20^{\text {th }}$ century philosophers and theologians have attempted to accommodate all objections to divine providence in a revised version. of divine creativity. The Hindu philosopher-statesman Sarvepalli Radhakrishnan identified the evolving universe with the creator: "The God who is responsible for this world, who is the consciousness of the universe, is working through brute matter from which $\mathrm{He}$ has to liberate himself and liberate us. He himself is suffering in each and all of us. This suffering will be at an end, when the spirit which is imprisoned in transitory matter is released, when the potential world-spirit of the whole becomes the actual consciousness of each part, when God becomes 'all in all', when the solitary limited God becomes the pantheistic God." ${ }^{15}$

The Christian theologian Karl SchmitzMoormann suggested to replace the Biblical notions of a Creator God by a Cosmic Force that is developing along with the universe: overall of immense intelligence and goodness, but neither perfect nor almighty and not omniscient. "One might describe the relationship between God and creation not as one of commanding, but as one of calling forth in love, by a God who does not impose a divine will... God does not seem to be interested in demonstrating almighty-ness, but in calling forth a creation able to encounter and love God - something a fully determined creature could never do. There is no love that is not free." ${ }^{56}$

According to the great biologist-scholar Ernst Mayr "[v]irtually all biologists are religious in the deeper sense of the word, even though it may be a religion without revelation, as Julian Huxley called it. The unknown, and perhaps unknowable, instills in us a sense of humility and awe." 57 Scientist-philosopher Stuart Kauffmann 58 expresses a similar idea when he says: "Life has emerged in the universe without requiring special intervention from a Creator God. Should that fact lessen our wonder at the emergence and evolution of life and the evolution of the biosphere? No! Since we hold life to be sacred, we are stepping towards the re-invention of the sacred as the creativity in nature." 59

Debunking reductionism and emphasizing ontological emergence as the main feature of the universe, and with it values, meaning, morals, consciousness, Kauffman sets out to 're-invent the sacred' which he sees revealed in the creativity of the universe: "We are the fruits of this biosphere. We can only have profound gratitude to participate in this ongoing evolution. The creativity in nature should truly be God enough for us. ${ }^{160}$ In the last chapter of the book Kauffmann refers to "some Jesuits, who are also cosmologists", who believe that God generated the vastness of the universe with some 400 billion galaxies each containing some 100 billion stars, but who 'cannot know when or where life will arise." ${ }^{61}$ He does not mention names but thinks that this theology that restricts the omniscience and omnipotence of God comes close to his own view: "This is a Generator God, outside of space 
and time, who does not know beforehand what will arise in the universe God has created... Neither God nor human beings know how the biosphere, the economy and the culture will evolve." Kauffmann acknowledges that his vision is close to the "old idea of God in nature, an immanent God, found in the unfolding of nature." ${ }^{62}$ Addressing the issues alluded to in the subtitle of his book, he continued: "We do not need to believe in or have faith in God as the unfolding of nature. This God is real. The split between reason and faith is healed. The split between reason and the rest of our humanity is healed. This that we discuss is a science, a world view, and a God with which we can live our lives forward forever into mystery." Kauffman recognizes that "the ancient religious traditions in the world have accumulated profound wisdom." He does believe that this is the foundation for a global ethic and ends with the wish to "reinvent the sacred for our planet, for all life and for ourselves." ${ }^{63}$ Kauffman re-connects, as he admits, with "old ideas": if not with the God of the Abrahamic tradition then certainly with the Brahman of Vedanta. We are not alone in a meaningless universe, but we have emerged at some point in time as one of the results of an endlessly creative nature capable of giving meaning to our lives and the world around us. We do not know in what ways nature will develop in the future, what kind of things will emerge in the next billion years of the existence of our universe, but we can assume that it will be full of novelty and surprise.

\section{Concluding remarks}

The enquiry into the nature of nature has at all times led to questions of origin and meaning. Throughout the ages and across cultures many have accepted the notion of a Divine Creator as humanly satisfying and intellectually defensible. Others found it impossible to reconcile human and non-human suffering in nature with the notion of an omniscient and omnipotent Supreme Being. Believers in a personal God not only constructed rational proofs for the existence of God but also sought out justifications of God. Modern science, while solving many a mystery of nature, remains ambiguous with regard to the existence and role of a Creator. Proofs for the existence of God as well as counter arguments can be found in all periods of history in East and West. Possibly the question is too large for our small human minds to cope with. That does not mean that it is meaningless to pursue it. Those who have engaged it - like the Christian Thomas Aquinas and the Hindu Vidyāranya Swāmī - encourage us to keep probing that ultimate mystery.

\section{NOTES}

${ }^{1}$ yukti: comprising the whole range of formal logic and argumentation, based on an agreed upon epistemology. 2 śruti: literally "what has been heard", comprising the oral as well as the written tradition, "revelation" granted to specially favored persons: the Veda and other Scriptures that are considered ultimate authority in matters of dharma.

${ }^{3}$ Śrīmadvidyāraṇyamunipranīta pañcadaśī tāmakựṣnakựtavyākhyayā etc. Nirnaya Sāgara Mudranāyalam, $7^{\text {th }}$ ed. Mumbai 1949 and Pañcadaśí of

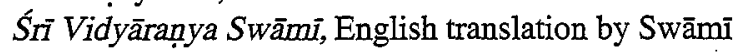
Swāhānanda, With an Introduction by Dr. T.M.P. Mahadevan: Sri Ramakrishna Math, Madras 1973. I have not always followed the English translation by Swāmī Swāhānanda but did my own.

${ }^{4}$ Sancti Thomae Aquinatis, Doctoris Angelici, Ordinis Praedicatorum SummaTheologiae cura Fratrum eiusdem_Ordinis Prima Pars Biblioteca de Autores Cristianos Matriti MCMLI. The translations are my own.

${ }^{5}$ Jacques Monod, Chance and Necessity: An Essay on the Natural Philosophy of Modern Biology, English translation. Vintage Books: New York 1972, p. 180.

${ }^{6}$ As Richard Dawkins, former Oxford Professor for the Popularization of Science does in his bestselling The God Delusion, Boston and New York, Houghton Mifflin Co. 2006.

${ }^{7}$ Francis S. Collin (a renowned microbiologist) Free Press 2006.

${ }^{8}$ Paul Davies (a reputable physicist) Touchstone Books 1995.

${ }^{9} \mathrm{I}$ am aware of the discussion of the authorship of the Pañcadaśî. As long as there is no conclusive evidence to the contrary, I am staying with its traditional attribution to Vidyāraṇya, one of the Śañkarācāryas of $14^{\text {th }}$ century India. The argument of the paper is not dependent on the question of its authorship.

${ }^{10}$ Francis Clooney has covered some of this in the second chapter of his Hindu God, Christian God, Oxford University Press 2001.

${ }^{11}$ Calvin considered-nature too corrupted and intellect too diminished by the "fall" to make them capable of 
finding God in nature. Karl Barth believed that natural theology "was at best unnecessary and at worst subverted and distorted divine revelation."

${ }^{12}$ See also J. Lauster and B. Oberdorfer (eds.) Der Gott der Vernunft: Protestantismus und vernünftiger Gottesgedanke, Mohr-Siebeck: Tübingen, 2009.

${ }^{13}$ Edited by Ted Peters, Westminster/John Knox Press, Louisville, Kentucky.

${ }^{14}$ The 2008 Riddell Lectures at the University of Newcastle.

${ }^{15}$ Science and Religion: A New Introduction; Second Edition, Wiley-Blackwell, 2010.

${ }^{16}$ Summa Theologica I, 2, 3: "Utrum Deus sit": "Deum esse quinque viis probari potest..."

${ }^{17}$ English Edition, Chicago: Loyola University Press, 1994 , para 1147.

${ }^{18}$ ibid. para 286.

${ }^{19}$ Tattvasañgraha of Ācārya Śāntarakșita with the commentary Pañjikā of Kāmalaśila critically edited by Swāmī Dwarikadass Shastri, 2 vols. Bauddha Bharati, Varanasi 1968. English translation by Ganganatha Jha, 2 vols., Baroda Oriental Institute, 1937.

${ }^{20}$ Śañkara Brahmasūtrabhāṣya II, 2,18ff.

${ }^{21}$ This type of argumentation is much older than Hume, to whom it is usually ascribed. The Jains, 2000 years ago, used it, too.

${ }^{22}$ Out of the six traditional Indian pramānas the Buddhists accepted only two: pratyakșa and anumāna.

${ }^{23}$ In a separate paper I shall be dealing with the Buddhist-Hindu debate about creation and creator.

${ }^{24}$ This view was shared by all Vedāntins. Even Madhva, the proponent of Dvaita - a fierce opponent to Śankara's Advaita - agreed: "Reason would not be able to prove the existence of God. It can always be countered by other reasons. " Apuvakhyana 5.

${ }^{25} \mathrm{I}$ am consciously using a mathematical term in the translation of viveka.

${ }^{26}$ PD I, 2.

${ }^{27}$ I am not going into question of the identity of the author of the Pañcadasín since it is not relevant to the issue at hand.

${ }^{28}$ It is arising from the impure sattva component of prakerti.

29 "The Arithmetic Paradox: The Oneness of Mind" in: Mind and Matter, p.140.

${ }^{30}$ My View of the World, 1964.

${ }^{31}$ David J. Chalmers, "The Puzzle of Conscious Experience" Scientific American, December 1995, pp.62-68.

${ }^{32}$ Joseph Weizenbaum, one of the scientists, who pioneered much of the technology for it, vehemently rejected the notion that these machines had anything to do with "intelligence". See also his essay "The Computer as Idol" in T. D. Singh and R. Gomatam (eds.) Synthesis of Science and Religion, The
Bhaktivedanta Institute, San Francisco and Bombay, 1988.

33 "Auch das Universum hat ein Bewusstsein," Der

Spiegel, 22/1988, pp. 216-20.

${ }^{34}$ Quoted in Ervin Laszlo, Science and the Re-

enchantment of the Cosmos, Inner Traditions:

Rochester 2006, p. 148.

${ }^{35}$ Science and the Akasbik Field: An Integral Theory of Everything, Inner Traditions: Rochester, $2^{\text {nd }}$ ed. 2007.

${ }^{36}$ The Unfinished Universe, Simon \& Schuster: New York, 1986.

${ }^{37}$ Ervin Laszlo, Science and the Akashik Field: An Integral Theory of Everything, Inner Traditions: Rochester, $2^{\text {nd }}$ ed. 2007, pp. 130 ff: "The Poetry of Akashik Vision."

${ }^{38}$ Aitareya Upanișad 3. 1.1. prajūānama brahma (Rgveda).

${ }^{39}$ Bṛhadāranyaka Upaniṣad 1. 4.10: aham brahmāsmi

(Yajurveda).

${ }^{40}$ Chāndogya Upaniṣad 6. 8.15: tat tvam asi

(Sāmaveda).

${ }^{41}$ Māṇụūkya Upaniṣad 2 (Atharvaveda).

${ }^{42}$ E.g. Jones Physics as Metaphor, New American

Library: Meridian 1982

${ }^{43}$ Summa theologica I, 8,1

${ }^{44}$ PD VI, 163.

${ }^{45}$ PD VI, 164.

${ }^{46} \mathrm{PD}$ VI, $165 \mathrm{f}$

${ }^{47}$ PD V, 8.

${ }^{48}$ James Jean, The Mysterious Universe, Cambridge University Préss, 1931, p. 139.

${ }^{49}$ The First Three Minutes, Bantam Books 1980, p. 144.

50 "Emergence" is a major new area of research in biology and the focus of contemporary science-andreligion studies. See e.g. The Re-Emergence of Emergence: The Emergency Hypothesis from Science to Religion, ed. by Philip Clayton and Paul Davies, Oxford University Press, 2006.

${ }^{51}$ Darwin himself assumed that life was initially breathed "by the Creator into a few forms or one". The Origin of Species, Mentor Books, 1964, p. 450.

${ }^{52}$ The Rebirth of Nature: The Greening of Science and God, Bantam Books 1992, p. 71.

${ }^{53}$ Ibid. p. 101.

${ }^{54}$ One of the most thorough treatments of this is offered by Nobel-Price winning geneticist Jacques Monod in his Chance and Necessity, advertised as "a philosophy for a universe without causality."

${ }^{55}$ East and West in Religion, London: George Allen \& Unwin, 1965, p. 124.

${ }^{56} \mathrm{I}$ took that quote from a paper that was distributed at a Templeton course-program meeting in Chicago in 1995. Inoticed that in his Theology of Creation in an 
Evolutionary World, Cleveland, Ohio: Pilgrim Press 1997, he is much more restrained and using more conventional theological expressions.

${ }^{57}$ The Growth of Biological Thought, The Belknap Press of Harvard University, 1982, p. 81.

${ }^{58}$ Stuart A. Kauffman, Reinventing the Sacred: A New View of Science, Reason and Religion, Basic Books: New York 2008.

${ }^{59}$ Op. cit. p. 71.

${ }^{60}$ Ibid. p. 100.

${ }^{61}$ Ibid. p. 283.

${ }^{62}$ Ibid. p. 288.

${ }^{63}$ Ibid. Last paragraph. 